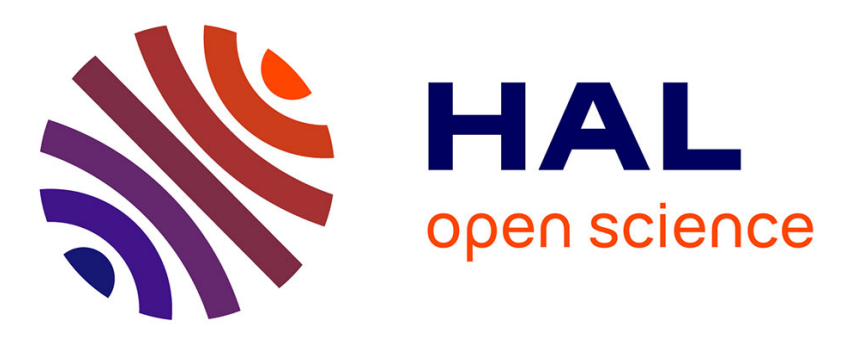

\title{
Ruthenium-Catalyzed Hydroformylation of the Functional Unsaturated Fatty Nitrile 10-Undecenitrile
}

\author{
Lucas Le Goanvic, Jean-Luc Couturier, Jean-Luc Dubois, Jean-François
}

Carpentier

\section{- To cite this version: \\ Lucas Le Goanvic, Jean-Luc Couturier, Jean-Luc Dubois, Jean-François Carpentier. Ruthenium- Catalyzed Hydroformylation of the Functional Unsaturated Fatty Nitrile 10-Undecenitrile. Journal of Molecular Catalysis A: Chemical, 2016, 417, pp.116-121. 10.1016/j.molcata.2016.02.030 . hal- 01290441}

HAL Id: hal-01290441

https://hal-univ-rennes1.archives-ouvertes.fr/hal-01290441

Submitted on 27 Apr 2016

HAL is a multi-disciplinary open access archive for the deposit and dissemination of scientific research documents, whether they are published or not. The documents may come from teaching and research institutions in France or abroad, or from public or private research centers.
L'archive ouverte pluridisciplinaire $\mathbf{H A L}$, est destinée au dépôt et à la diffusion de documents scientifiques de niveau recherche, publiés ou non, émanant des établissements d'enseignement et de recherche français ou étrangers, des laboratoires publics ou privés. 


\section{Ruthenium-Catalyzed Hydroformylation of the Functional Unsaturated Fatty Nitrile 10-Undecenitrile}

Lucas Le Goanvic, ${ }^{[a]}$ Jean-Luc Couturier, ${ }^{[\mathrm{b}]}$ Jean-Luc Dubois, ${ }^{[\mathrm{c}]}$ and Jean-François Carpentier $^{[\mathrm{a}], *}$

[a] Organometallics, Materials and Catalysis; UMR 6226 Institut des Sciences Chimiques de Rennes, CNRS-University of Rennes 1, F-35042 Rennes, France

${ }^{[b]}$ Arkema France, CRRA, BP 63, Rue Henri Moissan, F-69493 Pierre Bénite, France

${ }^{\text {[c] }}$ Arkema France, 420 Rue d'Estienne d'Orves, F-92705 Colombes, France

Graphical abstract

Abstract

The hydroformylation of 10-undecenitrile (1), a route towards polyamide-12, has been studied using Ru-diphosphite catalysts. The reactions proceeded effectively by in situ combination of chloro precursors such as $\mathrm{RuCl}_{2}\left(\mathrm{PPh}_{3}\right)_{3}$ and $\mathrm{RuCl}_{2}(\mathrm{DMSO})_{4}$ with Biphephos. High productivities (TON up to 15,000 mol(aldehyde).mol(Ru $)^{-1}$ ) were achieved by carrying the reactions at low catalyst loading $\left([1]_{0} /[\mathrm{Ru}]=20,000\right)$, at $120{ }^{\circ} \mathrm{C}$ in toluene or acetonitrile under 20 bars $\mathrm{CO} / \mathrm{H}_{2}(1: 1)$, with 20 equiv of Biphephos $v s$. Ru. Up to $75 \%$ chemoselectivity for the aldehydes and very high regioselectivities for the linear aldehyde $(l / b=99: 1)$ were reached under such optimized conditions. Lower loadings of Biphephos (down to 2.5 equiv. $v s$. $\mathrm{Ru}$ ) did not affect the chemo- and regioselectivities but the activity. The Ru-Biphephos combinations showed a non-optimized hydroformylation $\mathrm{TOF}_{\mathrm{HF}}$ of $c a \cdot 2-7 \mathrm{~min}^{-1}$, that is $c a$. 1-2 order of magnitude lower than that of analogous Rh-based systems $\left(\mathrm{TOF}_{\mathrm{HF}}=c a .80\right.$ $\min ^{-1}$ ). These Ru-Biphephos systems are, however, incapable, under the conditions suitable 
for selective hydroformylation, to promote isomerization of internal olefins, and hence to achieve a tandem isomerization-hydroformylation process.

Keywords: Hydroformylation, Isomerization, Ruthenium, Biphephos, 10-Undecenenitrile.

\section{Introduction}

If rhodium is irrefutably the most efficient metal to promote olefin hydroformylation, one of the most widely applied homogeneously-catalyzed processes in industry [1], its very high and volatile price has urged investigation on other metals [2]. In 1977, the relative activities of the unmodified metal carbonyl complexes in hydroformylation were suggested as follows: $\mathrm{Rh} \gg$ $\mathrm{Co}>\mathrm{Ir}, \mathrm{Ru}>\mathrm{Os}>\mathrm{Pt}>\mathrm{Pd} \gg \mathrm{Fe}>\mathrm{Ni}[3]$. However, recent reports have shown that those old assumptions should be re-examined; for instance, the activity ratio of rhodium-to-iridium is in fact much closer to 1 than the 10,000:1 ratio initially predicted [4,5]. Ruthenium may also offer an interesting compromise between price and activity, as it is currently $c a .15$ and 12 times cheaper than rhodium and iridium, respectively [6], and its activity in an oxo process is generally announced as one of the best (with iridium) among all alternative metals.

The first investigations on Ru-catalyzed hydroformylation began as early as in 1965 with Wilkinson's brief report on hydroformylation of 1-pentene using the mononuclear zerovalent complex $\mathrm{Ru}(\mathrm{CO})_{3}\left(\mathrm{PPh}_{3}\right)_{2}$ as catalyst precursor $\left(100-120{ }^{\circ} \mathrm{C}, 100 \mathrm{bar}, \mathrm{CO} / \mathrm{H}_{2}=\right.$ 1:1) [7]. The authors subsequently presented more detailed results for 1-hexene hydroformylation with the same catalyst system and other related mononuclear Ru-phosphine complexes; at a quite high catalyst loading $([$ olefin $] /[\mathrm{Ru}]=100)$, the turnover frequency (TOF) reached $0.075 \mathrm{~min}^{-1}$, with a claimed $100 \%$ chemoselectivity for the aldehydes in most cases, although the linear-to-branched ratio was low $(l / b=2.0-2.9)$ [8]. The $\mathrm{Ru}(\mathrm{II})$ dihydrido 
dicarbonyl complex $\mathrm{Ru}(\mathrm{H})_{2}(\mathrm{CO})_{2}\left(\mathrm{PPh}_{3}\right)_{2}$ was proposed as the principal active species. $\mathrm{Ru}_{3}(\mathrm{CO})_{12}$ proved to be a modest precursor ( $24 \%$ conv.) under the studied conditions but increased conversion was obtained upon addition of 1 equiv. (vs. $\mathrm{Ru}$ ) of $\mathrm{PPh}_{3}$ (88\% conv.) or, even better, $\mathrm{P}(\mathrm{OPh})_{3}(95 \%$ conv.); however, those systems were all less active than the mononuclear complexes. Meanwhile, Schulz and Bellstedt also reported hydroformylation of propylene with $\mathrm{Ru}_{3}(\mathrm{CO})_{12}$ to afford $94 \%$ of conversion, but the final mixture contained less than $25 \%$ of aldehydes [9].

Examples of 1-hexene hydroformylation conducted in an ethanol-water (80:20) mixture using water-soluble complexes of the type $\mathrm{K}[\mathrm{Ru}(\mathrm{EDTA}-\mathrm{H}) \mathrm{Cl}]$ were reported in 1988 [10]. At a high catalyst loading $\left([\right.$ olefin $] /[\mathrm{Ru}]=140 ; 130{ }^{\circ} \mathrm{C}, 50$ bar $\left.\mathrm{CO} / \mathrm{H}_{2} 1: 1\right)$, these led to full conversion of the olefin (overall $\mathrm{TOF}=0.2 \mathrm{~min}^{-1}$ ) and exclusive formation of linear heptanal.

Surprisingly, ruthenium-catalyzed hydroformylation with the ligands most often used nowadays in combination with rhodium, i.e. diphosphines and diphosphites, was not reported until recently. It is only in 2012 that Nozaki and coworkers reported on combinations of $\{\operatorname{RuCp}(\mathrm{acac})\}_{2}$ with Xantphos or Bisbi diphosphines, or the A4N3 diphosphite (Figure 1) [11]. The latter diphosphite ligand allowed reaching increased chemo- (up to 66\% aldehydes) and regioselectivities ( $l / b$ up to 79$)$ in the hydroformylation of 1-decene $\left(100{ }^{\circ} \mathrm{C}, 20\right.$ bar $\mathrm{CO} / \mathrm{H}_{2}$ 1:1); the side-products were essentially isomerized (internal) olefins (19\%) and a slight amount of the hydrogenation product (1.5\%). The catalyst loading was, however, quite high ([olefin]/[diphosphite]/[Ru] $=40: 2: 1)$ and overall TOFs were about $0.025 \mathrm{~min}^{-1}$.

Domino hydroformylation-hydrogenation reactions, to end up with the corresponding alcohols instead of the aldehydes, were also developed. Besides examples relying on rhodium complexes to achieve hydroformylation and ruthenium complexes for the hydrogenation 
reaction $[11,12]$, Beller and coworkers developed the first such domino reaction with the same ruthenium catalyst. Using $\mathrm{Ru}_{3}(\mathrm{CO})_{12}$ or $\mathrm{Ru}$ (methylallyl $)_{2}(\mathrm{COD})$ as precursor, combined with 1 equiv. (vs. Ru) of a 2-phosphino-substituted imidazole ligand, at a [olefin]/[Ru] ratio of 167, $130{ }^{\circ} \mathrm{C}$ and 60 bar $\mathrm{CO} / \mathrm{H}_{2}(1: 5)$, they achieved full conversion of 1-octene (overall $\mathrm{TOF}=$ $\left.0.13 \mathrm{~min}^{-1}\right)$ to provide $87 \%$ of alcohol $(l / b=10)$, along with $9 \%$ of octane and less than $1 \%$ of the intermediate aldehyde $[13,14]$.

In previous studies, we reported the use of Rh-Biphephos [15] and Ir-Biphephos [5c] catalyst systems for the tandem isomerization-hydroformylation $[16,17]$ of the unsaturated fatty nitrile 10-undecenitrile (1) (Scheme 1), as a route toward biosourced polyamide-12. Those systems performed at very high substrate-to-catalyst ratio $(20,000-100,000)$ and yielded the desired linear aldehyde (2) with high chemo- and regioselectivities up to $93 \%$ and 99\%, respectively. However, significant amounts of undesired isomerization products (1-int$\boldsymbol{x}$ ) along with minute amounts of the hydrogenation product (4) were formed, which eventually plague both conversions and selectivities for the desired linear aldehydes (Scheme 1). Preliminary experiments showed that potentially interesting results could be also reached with ruthenium catalysts, although the activities were apparently much lower [5c]. Herein we report full details on the isomerization-hydroformylation of 10-undecenitrile with such ruthenium-based systems. A variety of precursors and ligands, as well as regular reaction parameters (solvent, temperature, syngas pressure, substrate concentration), have been screened.

\section{Experimental Section}

\subsection{General features}


All reactions involving Ru-phosphine catalysts were performed under an inert atmosphere (argon) using standard Schlenk techniques. Solvents (toluene, THF, etc.) were purified over alumina columns using a MBraun system. $\mathrm{RuCl}_{2}\left(\mathrm{PPh}_{3}\right)_{3}, \mathrm{RuCl}_{2}\left(p\right.$-cymene) and $\mathrm{Ru}_{3}(\mathrm{CO})_{12}$ were generously provided by Umicore $\mathrm{Co}$ and stored in the glove box. $\mathrm{RuCl}_{2}(\mathrm{DMSO})_{4}$ was synthesized according to the literature procedure.[18] Biphephos and A4N3 diphosphite ligands were purchased from Strem Chemicals and MCAT, respectively, and used as received (stored in the glove box). 10-Undecenenitrile (typically $94 \%$ pure, contains $6 \%$ of 9undecenitrile (1-int-0) and other internal isomers (1-int-x), as determined by NMR) was supplied by Arkema; it was first eluted through a short alumina column and vacuum-distilled (Kügelrohr distillation) at $125{ }^{\circ} \mathrm{C}$ under $0.03 \mathrm{~mm} \mathrm{Hg}$ prior to use. ${ }^{1} \mathrm{H}$ and ${ }^{13} \mathrm{C} \mathrm{NMR}$ spectra were recorded on Bruker AC-300 and AM-400 spectrometers. ${ }^{1} \mathrm{H}$ and ${ }^{13} \mathrm{C}$ chemical shifts were determined using residual signals of the deuterated solvents and were calibrated $v s$. $\mathrm{SiMe}_{4}$

\subsection{General Procedure for Hydroformylation Reaction}

In a typical experiment, the ruthenium precursor $\mathrm{RuCl}_{2}\left(\mathrm{PPh}_{3}\right)_{3}$, as a 1.0 g. $\mathrm{L}^{-1}$ toluene solution $(0.72 \mathrm{~mL}, 0.75 \mu \mathrm{mol})$ was added on Biphephos $(11.8 \mathrm{mg}, 15.0 \mu \mathrm{mol})$ in a Schlenk flask. 10-undecenitrile (2.479 g, $15.0 \mathrm{mmol})$ in the desired solvent (toluene or acetonitrile, 15 $\mathrm{mL}$ ) was added onto the resulting mixture. The solution was transferred under argon into a 90 $\mathrm{mL}$ stainless-steel autoclave under argon, equipped with a magnetic stir bar cross. The reactor was sealed, charged with $\mathrm{CO} / \mathrm{H}_{2}$ at the desired pressure at room temperature, stirred $(800$ $\mathrm{rpm}$ ) and then heated with silicon oil set at the desired temperature. During the reaction, aliquots were sampled at regular time intervals to monitor the conversion and selectivities by NMR. After the appropriate reaction time, the reactor was cooled to room temperature and vented to atmospheric pressure. The solution was analyzed by NMR (after evaporation of 
solvent). The conversion of $\mathbf{1}$ into 1-int-x and $\mathbf{2 - 5}$, as reported in Tables 1-5, was calculated taking into account the quantity of internal isomers (1-int-x) initially present in the substrate: $\operatorname{Conv}(\mathbf{1})=\left([\mathbf{2}]_{t}+[\mathbf{3}]_{t}+[\mathbf{4}]_{t}+[\mathbf{5}]_{t}+[\mathbf{1 - i n t}-\boldsymbol{x}]_{t}-[\mathbf{1}-\text { int }-\boldsymbol{x}]_{\mathbf{0}}\right) /[\mathbf{1}]_{\mathbf{0}}$. The reported TOF values are overall values calculated from the conversion at total reaction time: $\mathrm{TOF}=\operatorname{conv} \times 20,0000 /$ time.

The NMR characteristics for 10-undecenenitrile (1), its internal isomers (1-int-x), the hydroformylation products ( 2 and 3 ) and the hydrogenation product (4) have been reported previously [5c,15]. Typical ${ }^{1} \mathrm{H}$ NMR signals for the linear alcohol (5) were observed at $\delta=$ $3.62\left(\mathrm{t}, J=6 \mathrm{~Hz}, 3 \mathrm{H}, \mathrm{HOCH}_{2} \mathrm{CH}_{2^{-}}\right) \mathrm{ppm}$.

\section{Results and Discussion}

First hydroformylation experiments were performed at low catalyst loading $\left([\mathbf{1}]_{0} /[\mathrm{Ru}]\right.$ = 20,000; initial 1/1-int- $\boldsymbol{x}$ ratio = 94:6) using different chloro $\mathrm{Ru}(\mathrm{II})\left(\mathrm{RuCl}_{2}\left(\mathrm{PPh}_{3}\right), \mathrm{RuCl}_{2}(p-\right.$ cymene), $\left.\mathrm{RuCl}_{2}(\mathrm{DMSO})_{4}\right)$ and $\mathrm{Cl}$-free $\mathrm{Ru}(0)\left(\mathrm{Ru}_{3}(\mathrm{CO})_{12}\right)$ precursors in combination with Biphephos, diphosphite A4N3 or triphenylphosphite. For the sake of comparison, the experimental conditions used were those optimized in the hydroformylation of $\mathbf{1}$ using $\mathrm{Rh}(\mathrm{acac})(\mathrm{CO})_{2}$-Biphephos [15].

\subsection{Preliminary Notes}

It is here important to point out that the chemo-/regioselectivities remained constant over time, and no obvious change in the kinetic regime was noted, indicating the stability of all these catalytic systems over the reaction course. This indicates, in particular, that these $\mathrm{Ru}$ catalyst systems were not affected by the $\mathrm{HCl}$ released from the chloro precursors, which is in contrast with the highly sensitive Rh-based systems. Also, all the experiments reported in the forthcoming tables were at least duplicated, showing a good reproducibility. One necessary 
condition is required to achieve such reproducibility, that is the use of freshly prepared (i.e., no older than one week) stock solutions of the Ru precursor, stored in the dark. Because of the low catalyst loading, such stock solutions were needed to introduce accurately small amounts of the $\mathrm{Ru}$ precursor. These stock solutions are perfectly clear $\left(\mathrm{RuCl}_{2}\left(\mathrm{PPh}_{3}\right)_{3}\right.$ : orange, $\mathrm{RuCl}_{2}(\mathrm{DMSO})_{4}$ : yellow); yet, we observed that over days-weeks, upon exposure to light, some of these solutions can turn blackish, suggesting the formation of metal colloids/nanoparticles; in those cases, we observed that the chemoselectivity for aldehydes can dramatically drop from $75 \%$ down to $60 \%$ (mainly in favor of hydrogenation and also isomerization products), while the regioselectivity slightly dropped from 99.0:1.0 down to 98.5:1.5. We also noted that old, still clear solutions to the naked eye can lead to decreased selectivities.

\subsection{Catalyst Precursor}

Significant differences in terms of activity were noted among the four precursors investigated. Representative results are summarized in Table 1. Both $\mathrm{RuCl}_{2}\left(\mathrm{PPh}_{3}\right)_{3}$ and $\mathrm{RuCl}_{2}(\mathrm{DMSO})_{4}$ led to the higher activities with, respectively, important and full conversion of the substrate under the chosen conditions $\left(\mathrm{TOF}_{\mathrm{HF}}=5\right.$ and $6 \mathrm{~min}^{-1}$, entries 1 and 4 , respectively). On the other hand, the chemoselectivity for aldehydes was very similar for all systems. This selectivity is quite comparable to that obtained with the Rh-Biphephos catalytic system [15], so as the regioselectivity $(2 / 3 ; l / b$ up to $c a$. 120$)$; only the system based on $\mathrm{RuCl}_{2}$ (p-cymene) was somewhat less regioselective. The close similarity of the regioselectivity achieved with $\mathrm{Cl}$ containing and $\mathrm{Cl}$-free $\left(\mathrm{Ru}_{3}(\mathrm{CO})_{12}\right)$ precursors is noteworthy (vide supra). The 1-int-0/1-int-x $(x>0)$ ratio indicates the isomerization ability of the system: the lower this ratio, the more important the isomerization of the double bound inside the carbon chain. In fact, those $\mathrm{Ru}$ systems proved moderately isomerizing, since most of them led essentially to 9-undecenitrile 
with quite minor amounts of more internal isomers. A consequence of this low isomerizing ability is that, even upon long exposure $(75 \mathrm{~h})$ after full conversion of $\mathbf{1}$, the amount of internal isomers 1-int-x did not decrease significantly. The final amount of hydrogenated product (4) is similar in $\mathrm{Ru}$ systems as in the Rh ones (ca. 2-5\%). Noteworthy, in contrast to Rh-based catalysts but in line with Ru systems [10-14], small amounts $(<0.5 \mathrm{~mol} \%)$ of alcohol products (5)19 can be observed. Further experiments were conducted using the two most efficient precursors, i.e., $\mathrm{RuCl}_{2}\left(\mathrm{PPh}_{3}\right)_{3}$ and $\mathrm{RuCl}_{2}(\mathrm{DMSO})_{4}$.

\subsection{Solvent}

The dependence of the performance of the $\mathrm{RuCl}_{2}\left(\mathrm{PPh}_{3}\right)_{3^{-}}$and $\mathrm{RuCl}_{2}(\mathrm{DMSO})_{4}$ - $\mathrm{Biphephos}$ systems on the solvent nature was evaluated with toluene, acetonitrile, DMF, diglyme and 1,2-dichloroethane (DCE). The results are summarized in Table 2. The trends observed with $\mathrm{RuCl}_{2}\left(\mathrm{PPh}_{3}\right)_{3}$ are identical to those with $\mathrm{RuCl}_{2}(\mathrm{DMSO})_{4}$. Hence, acetonitrile, DMF and toluene featured similar results in terms of conversion of $\mathbf{1}$ and chemoselectivity for aldehydes. Nevertheless, if the regioselectivity was as good as the one obtained with toluene for acetonitrile, DMF induced a slightly more important amount of branched aldehyde. On the other hand, both 1,2-dichloroethane and diglyme led to low substrate conversion and also a slightly lower regioselectivity. There is no apparent correlation between the solvent polarity and the catalytic performance. Hence, this screening allowed us to highlight two couples of efficient precursors $-\mathrm{RuCl}_{2}\left(\mathrm{PPh}_{3}\right)_{3}$ and $\mathrm{RuCl}_{2}(\mathrm{DMSO})_{4}-$ and solvents-toluene and acetonitrile.

\subsection{Ligands}

The A4N3 ligand (Figure 1) used by Nozaki et al. [11] and triphenylphosphite, a simple monophosphite ligand, were evaluated in comparison with Biphephos, in combination with $\mathrm{RuCl}_{2}\left(\mathrm{PPh}_{3}\right)_{3}$ (similar results were obtained upon using $\left.\mathrm{RuCl}_{2}(\mathrm{DMSO})_{4}\right)$ under the same reactions conditions than the standard experiments presented above; the amounts of ligands 
were adjusted to match the same phosphorus-to-metal ratio. Unsurprisingly, the $\mathrm{P}(\mathrm{OPh})_{3^{-}}$ based system exhibited a lower activity and chemoselectivity and a much poorer regioselectivity $(l / b=4.5)$ as compared to the two other systems based on diphosphite ligands. The A4N3 ligand exhibited a slightly lower activity (TOF $=3-5 \mathrm{~min}^{-1}$ ) and also a slightly decreased regioselectivity than the equivalent Ru-Biphephos system. The same trend was also observed in the case of Rh-based catalysts in previous studies carried in our lab [20]. On the other hand, very poor performances were observed with Zhang's tetraphosphine [21].22

\section{5. [Ligand]/[Ru] ratio}

In our standard conditions, a ligand-to-Ru ratio of 20 is used. In the case of Rh-Biphephos catalysis, this condition proved to be necessary to prevent catalyst decay and decreased activities and selectivities, assumed to arise from the formation of rhodium aggregates [15]. With ruthenium, the amount of ligand introduced may not need to be necessary as high as in the case of rhodium to prevent such phenomenon. Thus, experiments at [Biphephos]/[Ru] ratios in the range 0-20 were carried out; the results are summarized in Table 4. Experiments conducted without Biphephos ligand proved to be inefficient to perform hydroformylation of undecenitrile in $88 \mathrm{~h}$; at the end of these experiments, a black suspension was recovered, suggesting the formation of ruthenium aggregates. Formation of these aggregates was prevented by stabilization of the metal center with the diphosphite ligand. In these experiments, no impact was observed regarding the selectivities, i.e., the $l / b$ ratio and $\% \mathrm{HF}$ did not change significantly when the $[$ Biphephos $] /[\mathrm{Ru}]$ was modified, indicating that the same active species is at work in all cases. However, a noticeable increase in the catalytic activity was noted when the $[$ Biphephos $] /[\mathrm{Ru}]$ ratio increased. Although this may appear counterintuitive at first sight, this observation can be rationalized by taking into account that, at such a high substrate-to-catalyst ratio $(20,000)$, excess ligand induces larger amounts of 
active species, possibly by counter-balancing competitive coordination of the substrate to the metal precursor.

\subsection{Temperature, Pressures}

Considering the moderate activity of the Ru-based systems, experiments performed at higher temperatures with the $\mathrm{RuCl}_{2}\left(\mathrm{PPh}_{3}\right)_{3} /$ Biphephos system were first envisioned. The compositions profiles and selectivities obtained at $140{ }^{\circ} \mathrm{C}$, instead of $120{ }^{\circ} \mathrm{C}$, are presented in Figure 2 and Table 5. As expected, an increase of the global reaction rate was observed at 140 ${ }^{\circ} \mathrm{C}$. However, the isomerization process was much more favored at this temperature, as compared to $120{ }^{\circ} \mathrm{C}$; the amount of internal olefins increased from $22 \%$ to $40 \%$ and the selectivity in hydroformylation products concomitantly dropped from $76 \%$ down to $58 \%$. The significantly larger amount of internals olefins that migrated at least twice $\left(\mathbf{1}\right.$-int- $\boldsymbol{x} ; \boldsymbol{x}=\mathbf{0} / \mathbf{1}^{+}=$ 88:12) underscores the importance of the isomerization process. The relative pseudo zerothorder rates ${ }^{[} 3^{]}$of hydroformylation $v s$. isomerization, as determined from the initial rates in Figure 2 and expressed as $k_{\mathrm{HF}} / k_{\mathrm{Iso}}$, decreased from 4.6 at $120{ }^{\circ} \mathrm{C}$ down to 1.4 at $140{ }^{\circ} \mathrm{C}$; this corresponds to a difference in activation energies $E_{\mathrm{a}, \mathrm{Iso}}-E_{\mathrm{a}, \mathrm{HF}}$ of $c a .8 \mathrm{~kJ} \mathrm{~mol}^{-1}$. It is noteworthy that even at the latter high temperature, conversion of the internal isomers 1-int-x to aldehydes did not proceed at a noticeable rate (see Figure 2); this evidences the impossibility, at least with the present catalyst systems, to achieve a tandem isomerizationhydroformylation process [17]. Yet, the increase in temperature from 120 to $140{ }^{\circ} \mathrm{C}$ only had a minimal impact on the $l / b$ ratio and, more surprisingly, on the chemoselectivity (in particular, larger amounts of alcohols may have been anticipated since this is a consecutive, more energy-demanding process).

Modification of the total and relative pressures is likely to influence the formation of active species and/or lead to different catalytic species, and eventually affect activities and selectivities [24]. Representative results of such variations in the $\mathrm{RuCl}_{2}\left(\mathrm{PPh}_{3}\right)_{3} / \mathrm{Biphephos}$ 
system are presented in Table 6 . When the total syngas pressure was varied in the range 10-40 bars, at a constant $1: 1 \mathrm{CO} / \mathrm{H}_{2}$ ratio, the reactions proceeded with just slightly decreased activity (from 5.0-6.1 $\mathrm{min}^{-1}$ down to $3.5 \mathrm{~min}^{-1}$ ) and quite similar selectivities (entries 25, 26 and 29). A much more significant decrease of the catalytic activity was observed at 90 bars, where the TOF dropped down to $0.6 \mathrm{~min}^{-1}$; meanwhile, the amount of branched aldehyde was doubled while the chemoselectivity remained constant (entry 30). The same trends were observed upon changing the $\mathrm{CO} / \mathrm{H}_{2}$ ratio to 3:1 at a total pressure of 20 bars (entry 28). Obviously, excess $\mathrm{CO}$ is detrimental. On the other hand, when the $\mathrm{CO} / \mathrm{H}_{2}$ ratio was set at 1:3, the activity somehow decreased but most noticeably, the chemoselectivity for aldehydes dramatically decreased; in particular, larger amounts of alcohols 5 were formed, a nonunexpected result (entry 27).

\subsection{Recycling}

Attempts to recycle the catalyst and eventually improve on the catalytic productivity were conducted. We used the same procedure as the one positively evaluated for the analogous RhBiphephos system [15a]: the vacuum distillation of the crude reaction mixture can be readily achieved, allowing complete elimination of toluene solvent, and recovery of analytically pure aldehydes (along with residual internal olefins) and of a solid residue that contains the catalyst/ligand. To prevent deteriorated performance, the solid residue was concentrated and recovered under an inert atmosphere. Representative results obtained using this procedure are gathered in Table 7; the runs were conducted over long time period (124-190 h) to achieve high conversions. The results evidence that effective recycling can be achieved, maintaining a good chemo- and regioselectivity in favor of the linear aldehyde over at least three runs; the overall TON thus reached 55,000. The addition of a novel charge of fresh Biphephos in the recycling runs does not appear essential (compare run 2 and run 3). Yet, a ${ }^{31} \mathrm{P}$ NMR monitoring of the reaction mixture was also performed, indicating that the Biphephos ligand slowly degrades under the reaction conditions (see the Supporting Information, Figure S1); similar observations were made with the Rh-Biphephos catalyst system [15a]. 


\section{Conclusions}

Combination of $\mathrm{Ru}(\mathrm{II})$ metallic precursors with Biphephos affords a selective catalytic system for the hydroformylation of 10-undecenitrile. The selectivity data: $75 \%$ of hydroformylation and $l / b$ ratio up to $99: 1$, compare favorably with the very good performance of the rhodiumand iridium-based catalysts we previously reported [5c,15]. Formation of the hydrogenated olefin and of the alcohols resulting from the reduction of the desired aldehydes can be prevented by an adequate choice of the temperature and $\mathrm{CO} / \mathrm{H}_{2}$ pressures. These good chemoand regio-selectivities are balanced with the lower activity (non-optimized hydroformylation $\mathrm{TOF}_{\mathrm{HF}}$ of 2-7 $\mathrm{min}^{-1}$ ), which are decreased by $\mathrm{ca}$. 1-2 orders of magnitude (and not 5 orders as initially anticipated) in comparison with equivalent $\mathrm{Rh}$-Biphephos systems $\left(\mathrm{TOF}_{\mathrm{HF}}=c a .80\right.$ $\min ^{-1}$ ), although the lower prices of ruthenium ( $c a .15$ times cheaper than $\mathrm{Rh}$ and Ir) must also be taken into account. This reduced activity did not hamper to achieve very high productivities (effective TurnOver Numbers for aldehydes, TON, up to 15,000 for batch experiments and up to 55,000 upon recycling). A limitation of these ruthenium systems is their incapacity, under the conditions suitable for selective hydroformylation, to promote isomerization of internal olefins, and hence to achieve a tandem isomerizationhydroformylation process as the Rh-Biphephos system is amenable to; we assume that this reflects the lower isomerizing ability of putative Ru-hydride species generated in these systems as compared to the corresponding Rh-hydride species in the Rh-based systems. Also, these ruthenium-based systems seem to be more versatile than the rhodium ones, as important isomerization or loss of regioselectivity can occur more easily if freshness of the catalyst precursors is not perfectly controlled.

\section{Supporting Information Available}

${ }^{31} \mathrm{P}\left\{{ }^{1} \mathrm{H}\right\}$ NMR monitoring of reaction media. 


\section{Acknowledgements}

This work was supported by the French National Research Agency, ANR project MEMCHEM (14-CE06-0022-02) and Arkema Co. We thank Umicore Co. (Dr. Angelino Doppiu) for a generous gift of $\mathrm{RuCl}_{2}\left(\mathrm{PPh}_{3}\right)_{3}, \mathrm{RuCl}_{2}\left(p\right.$-cymene) and $\mathrm{Ru}_{3}(\mathrm{CO})_{12}$.

\section{References}

[1] Corresponding author: Fax: (+33)(0)223-236-939. E-mail: jeanfrancois.carpentier@univ-rennes1.fr

[2] a) Rhodium Catalysed Hydroformylation (Eds.: P. W. N. M. van Leeuwen, C. Claver), Kluwer, Dordrecht, 2000; (b) C. D. Frohning, C. W. Kohlpaintner, M. Gauß, A. Seidel, P. Torrence, P. Heymanns, A. Höhn, M. Beller, J. F. Knifton, A. Klausener, J.-D. Jentsch, A. M. Tafesh (Eds.: B. Cornils, W. A. Herrmann), in Applied Homogeneous Catalysis with Organometallic Compounds: 2nd Edition, Wiley VCH, Weinheim, 2008, 27.

[3] J. Pospech, I. Fleischer, R. Franke, S. Buchholz, M. Beller, Angew. Chem. Int. Ed. 52 (2013) 2852-2872.

[4] R. Franke, D. Selent, A. Börner, Chem. Rev. 112 (2012) 5675-5732.

[5] G. Protzmann, K.-D. Wiese, Erdol Erdgas Kohle 117 (2011) 235.

[6] For examples of recent developments in Ir-catalyzed hydroformylation, see; (a) I. Piras, R. Jennerjahn, R. Jackstell, A. Spannenberg, R. Franke, M. Beller, Angew. Chem. Int. Ed. 50 (2011) 280-284; (b) C. Kubis, W. Baumann, E. Barsch, D. Selent, M. Sawall, R. Ludwig, K. Neymeyr, D. Hess, R. Franke, A. Börner, ACS Catal. 4 (2014) 2097-2108; (c) J. Ternel, J.-L. Couturier, J.-L. Dubois, J.-F. Carpentier, ChemCatChem 7 (2015) 513-520.; (d) 
A. Behr, A. Kämper, R. Kuhlmann, A. J. Vorholt, R. Franke, Catal. Sci. Technol. 6 (2016) 208-214.

[7] (a) http://www.infomine.com/investment/metal-prices; (b)

http://www.platinum.matthey.com/prices/price-charts.

[8] D. Evans, J. A. Osborn, F. H. Jardine, G. Wilkinson, Nature 208 (1965) 1203-1204.

[9] R. A. Sanchez-Delgado, J. S. Bradley, G. Wilkinson, J. Chem. Soc. Dalton Trans. (1976) 399-404.

[10] H. F. Schulz, F. Bellstedt, Ind. Eng. Chem. Prod. Res. Dev. 12 (1973) 176-183.

[11] M. Taqui Khan, S. B. Halligudi, S. H. R Abdi, J. Mol. Catal. 48 (1988) 313-317.

[12] (a) K. Takahashi, M. Yamashita, Y. Tanaka, K. Nozaki, Angew. Chem. Int. Ed. 51 (2012) 4383-4387.; (b) For the use of similar catalyst systems in tandem isomerizationhydroformylation, see: Y. Yuki, K. Takahashi, Y. Tanaka, K. Nozaki, J. Am. Chem. Soc. 135 (2013) 17393-17400.

[13] J. Zakzeski, H. Ryun Lee, Y. Ling Leung, A. T. Bell, Appl. Catal. A: Gen. 374 (2010) 201-212.

[14] (a) L. Wu, I. Fleischer, R. Jackstell, I. Profir, R. Franke, M. Beller, J. Am. Chem. Soc. 135 (2013) 14306-14312.; (b) I. Fleischer, L. Wu, I. Profir, R. Jackstell, R. Franke, M. Beller, Chem. Eur. J. 19 (2013) 10589-10594.; (c) For a similar system using water and $\mathrm{LiCl}$ as additives, see: I. Fleischer, K. M. Dyballa, R. Jennerjahn, R. Jackstell, R. Franke, A. Spannenberg, M. Beller, Angew. Chem. Int. Ed. 52 (2013) 2949-2953.

[15] For a related $\mathrm{Ru}_{3} \mathrm{CO}_{12}$-monophosphite catalyst system enabling the reverse water-gasshift (RWGS) domino hydroformylation-reduction of 1-olefins using a $\mathrm{CO}_{2} / \mathrm{H}_{2}$ (1:1) mixture instead of $\mathrm{CO} / \mathrm{H}_{2}$, see: Q. Liu, L. Wu, I. Fleischer, D. Selent, R. Franke, R. Jackstell, M. Beller, Chem. Eur. J. 20 (2014) 6888- 6894. 
[16] (a) J. Ternel, J.-L. Couturier, J.-L. Dubois, J.-F. Carpentier, Adv. Synth. Catal. 355 (2013) 3191-3204. B) ibid. WO Pat. 2014/195493 A1 (11/12/2014) (to Arkema and CNRS).

[17] M. Vilches-Herrera, L. Domke, A. Börner, ACS Catal. 4 (2014) 1706-1724.

[18] V. Goldbach, P. Roesle, S. Mecking, ACS Catal. 5 (2015) 5951-5972.

[19] P. Evans, A. Spencer, G. Wilkinson, J. Chem. Soc. Dalton Trans. 2 (1973) 204-209.

[20] Since alcohols are quite minor products in this process, only the linear alcohol derived from the major linear aldehyde is considered.

[21] L. Le Goanvic, J.-F. Carpentier, unpublished results.

[22] (a) S. Yu, X. Zhang, Y. Yan, C. Cai, L. Dai, X. Zhang, Chem. Eur. J. 16 (2010) 4938-

4943.; (b) C. Cai, S. Yu, G. Liu, X. Zhang, X. Zhang, Adv. Synth. Catal. 353 (2011) 26652670 .

[23] Under standard conditions (Table 3), this tetraphosphine afforded only $1 \%$ conversion within $42 \mathrm{~h}$.

[24] As observed in Figure 2, most reactions followed an apparent zeroth-order on 10undecenitrile, with the rate slightly accelerating in the latter stages of the reaction. In the absence of detailed mechanistic studies, exact reasons for this behavior remain unclear. This observation might suggest the progressive formation of active species over time, possibly resulting from decomposition of species formed in the earlier stages of the reaction.

[25] N. Sudheesh, S. K. Sharma, R. S. Shukla, R. V. Jasra, J. Mol. Catal. A: Chem. 316 (2010) 23-29. 
Figure caption

Figure 1. Diphosphine and diphosphite ligands used for ruthenium-catalyzed hydroformylation

Figure 2: Distribution of substrate and products $(\diamond \mathbf{1}, \mathbf{\square}$ 1-int-x, $\boldsymbol{\Delta} \mathbf{2}+\mathbf{3})$ as a function of time at $120{ }^{\circ} \mathrm{C}$ and $140{ }^{\circ} \mathrm{C}$ in the hydroformylation of 10 -undecenitrile by the $\mathrm{RuCl}_{2}\left(\mathrm{PPh}_{3}\right)_{3} / \mathrm{Biphephos} \mathrm{system.}$

Scheme 1. Aldehydes and side-products arising from the hydroformylation-isomerization of 10-undecenitrile (1)

Table caption

Table 1. Variation of precursor in Ru-catalyzed hydroformylation of 10-undecenitrile. ${ }^{\mathrm{a}}$

\begin{tabular}{|c|c|c|c|c|c|c|c|c|c|c|c|c|}
\hline Entry & $\mathrm{Ru}$ precursor & Time & 1 & $\begin{array}{c}1- \\
\text { int- } x\end{array}$ & 1-int-x & $2+3$ & $2 / 3$ & 4 & 5 & $\begin{array}{c}\text { Conv. } \\
\mathbf{1} \\
\end{array}$ & $\mathrm{HF}$ & $\mathrm{TOF}^{\mathrm{f}}$ \\
\hline & & {$[\mathrm{h}]$} & {$[\%]^{\mathrm{b}}$} & {$[\%]^{\mathrm{b}}$} & $x=0 / 1^{+}$ & {$[\%]^{\mathrm{b}}$} & $(l / b)^{\mathrm{c}}$ & {$[\%]^{\mathrm{b}}$} & {$[\%]^{\mathrm{b}}$} & {$[\%]^{\mathrm{d}}$} & {$[\%]^{\mathrm{e}}$} & {$\left[\min ^{-1}\right]$} \\
\hline 1 & $\mathrm{RuCl}_{2}\left(\mathrm{PPh}_{3}\right)_{3}$ & 48 & 10 & 22 & $98: 2$ & 63 & $99.1: 0.9$ & 4 & 0.3 & 89 & 76 & 6 \\
\hline 2 & $\mathrm{RuCl}_{2}(p$-cymene $)$ & 48 & 55 & 15 & $99: 1$ & 27 & $98.5: 1.5$ & 3 & 0.4 & 42 & 69 & 3 \\
\hline 3 & {$\left[\mathrm{Ru}(\mathrm{COD}) \mathrm{Cl}_{2}\right]_{n}$} & 48 & 62 & 13 & nd & 23 & 99.1:0.9 & 2 & traces & 34 & 72 & 2 \\
\hline 4 & $\mathrm{RuCl}_{2}(\mathrm{DMSO})_{4}$ & 48 & 0 & 24 & $92: 8$ & 71 & $98.9: 1.1$ & 5 & 0.5 & 100 & 75 & 7 \\
\hline 5 & $\mathrm{Ru}_{3}(\mathrm{CO})_{12}$ & 64 & 45 & 16 & $99: 1$ & 36 & $99.2: 0.8$ & 2 & 0 & 51 & 75 & 3 \\
\hline
\end{tabular}

${ }^{[\mathrm{a}]}$ Reaction conditions: $[\mathbf{1}]_{0} /[1-\text { int }-\boldsymbol{x}]_{0}(94: 6)=5.0 \mathrm{mmol},[\mathbf{1}]_{0} /[\mathrm{Ru}]=20,000$, $[$ Biphephos $] /[\mathrm{Ru}]=20$, toluene $(5$ $\mathrm{mL}$ ), $\mathrm{CO} / \mathrm{H}_{2}=1: 1, \mathrm{P}_{\mathrm{tot}}=20 \mathrm{bar}, T=120{ }^{\circ} \mathrm{C}$. ${ }^{[\mathrm{b}]}$ Distribution (mol-\%) of remaining 1, internal alkenes 1-int-x (residual or formed during the reaction; $\boldsymbol{x}=\mathbf{0 / \mathbf { 1 } ^ { + }}$ refers to the positioning of the internal $\mathrm{C}=\mathrm{C}$ bond, $x=0$ being 9undecenitrile and $x=1+$ referring to 8-, 7-, ...undecenitriles; please refer to Scheme 1), aldehydes 2 and $\mathbf{3}$, hydrogenated product $\mathbf{4}$, and alcohols 5 resulting from aldehydes reduction, as determined by ${ }^{1} \mathrm{H}$ NMR analyses. ${ }^{[\mathrm{c}]}$ Regioselectivity as determined by the linear-to-branched aldehyde ratio. ${ }^{[\mathrm{d}]}$ Conversion of $\mathbf{1}$ into $\mathbf{1 - i n t - \boldsymbol { x }}$ and 2-5, calculated taking into account the quantity of 1-int- $\boldsymbol{x}$ initially present in the substrate: Conv $=\left([\mathbf{2}]_{t}+[\mathbf{3}]_{t}+\right.$ $\left.[\mathbf{4}]_{t}+[\mathbf{5}]_{t}+[\mathbf{1}-\mathbf{i n t}-\boldsymbol{x}]_{t}-[\mathbf{1 - i n t}-\boldsymbol{x}]_{\mathbf{0}}\right) /[\mathbf{1}]_{\mathbf{0}}$. ${ }^{[\mathrm{e}]}$ Chemoselectivity as determined by the percentage of hydroformylation among all other competitive processes. ${ }^{[\mathrm{f}]}$ Overall TOF determined from the conversion of 1 over the whole reaction time.

Table 2: Solvent comparison in the Ru-catalyzed hydroformylation of 10-undecenitrile. ${ }^{\text {a }}$ 


\begin{tabular}{|c|c|c|c|c|c|c|c|c|c|c|c|c|c|}
\hline Entry & $\mathrm{Ru}$ precursor & solvent & time & 1 & 1-int-x & $1-$ int- $x$ & $2+3$ & $2 / 3$ & 4 & 5 & $\begin{array}{c}\text { Conv. } \\
\mathbf{1}\end{array}$ & $\mathrm{HF}$ & $\mathrm{TOF}^{\mathrm{f}}$ \\
\hline & & & {$[\mathrm{h}]$} & {$[\%]^{\mathrm{b}}$} & {$[\%]^{\mathrm{b}}$} & $x=0 / 1^{+}$ & {$[\%]^{\mathrm{b}}$} & $(l / b)^{\mathrm{c}}$ & {$[\%]^{\mathrm{b}}$} & {$[\%]^{\mathrm{b}}$} & {$[\%]^{\mathrm{d}}$} & {$[\%]^{\mathrm{e}}$} & {$\left[\min ^{-1}\right]$} \\
\hline 6 & $\mathrm{RuCl}_{2}\left(\mathrm{PPh}_{3}\right)_{3}$ & toluene & 48 & 10 & 22 & $98: 2$ & 63 & 99.1:0.9 & 4 & 0.3 & 89 & 76 & 6 \\
\hline 7 & $\mathrm{RuCl}_{2}\left(\mathrm{PPh}_{3}\right)_{3}$ & $\mathrm{CH}_{3} \mathrm{CN}$ & 48 & 10 & 22 & $97: 3$ & 64 & $99.2: 0.8$ & 4 & 0.3 & 89 & 77 & 6 \\
\hline 8 & $\mathrm{RuCl}_{2}\left(\mathrm{PPh}_{3}\right)_{3}$ & DMF & 50 & 22 & 19 & $97: 3$ & 56 & $98.7: 1.3$ & 3 & 0 & 76 & 80 & 5 \\
\hline 9 & $\mathrm{RuCl}_{2}\left(\mathrm{PPh}_{3}\right)_{3}$ & diglyme & 44 & 41 & 20 & $99: 1$ & 37 & $98.8: 1.2$ & 2 & 0 & 55 & 72 & 4 \\
\hline 10 & $\mathrm{RuCl}_{2}\left(\mathrm{PPh}_{3}\right)_{3}$ & DCE & 48 & 77 & 14 & $96: 4$ & 4 & $98.0: 2.0$ & 4 & traces & 16 & 36 & 1 \\
\hline 11 & $\mathrm{RuCl}_{2}(\mathrm{DMSO})_{4}$ & toluene & 48 & 0 & 24 & $92: 8$ & 71 & 98.9:1.1 & 5 & 0.5 & 100 & 75 & 7 \\
\hline 12 & $\mathrm{RuCl}_{2}(\mathrm{DMSO})_{4}$ & $\mathrm{CH}_{3} \mathrm{CN}$ & 48 & 1 & 25 & $93: 7$ & 70 & 99.1:0.9 & 4 & 0 & 99 & 76 & 7 \\
\hline 13 & $\mathrm{RuCl}_{2}(\mathrm{DMSO})_{4}$ & DMF & 47 & 5 & 31 & $94: 6$ & 60 & $98.6: 1.4$ & 4 & 0 & 95 & 68 & 7 \\
\hline 14 & $\mathrm{RuCl}_{2}(\mathrm{DMSO})_{4}$ & diglyme & 48 & 70 & 11 & nd & 16 & $97.5: 2.5$ & 3 & nd & 25 & 68 & 2 \\
\hline
\end{tabular}

${ }^{\text {[a] }}$ See Table 1.

Table 3: Ligand comparison in the Ru-catalyzed hydroformylation of 10-undecenitrile. ${ }^{\text {a }}$

\begin{tabular}{ccccccccccccc}
\hline Entry & Ligand & Time & $\mathbf{1}$ & $\mathbf{1 - i n t - \boldsymbol { x }}$ & $\mathbf{1 - i n t - \boldsymbol { x }}$ & $\mathbf{2 + 3}$ & $\mathbf{2 / 3}$ & $\mathbf{4}$ & $\mathbf{5}$ & $\begin{array}{c}\text { Conv. } \\
\mathbf{1}\end{array}$ & $\mathrm{HF}$ & $\mathrm{TOF}^{\mathrm{f}}$ \\
\hline & & {$[\mathrm{h}]$} & {$[\%]^{\mathrm{b}}$} & {$[\%]^{\mathrm{b}}$} & $\boldsymbol{x}=\mathbf{0} / \mathbf{1}^{+}$ & {$[\%]^{\mathrm{b}}$} & $(\mathrm{llb})^{\mathrm{c}}$ & {$[\%]^{\mathrm{b}}$} & {$[\%]^{\mathrm{b}}$} & {$[\%]^{\mathrm{d}}$} & {$[\%]^{\mathrm{e}}$} & {$\left[\mathrm{min}^{-1}\right]$} \\
\hline 15 & Biphephos & 48 & 10 & 22 & $97: 3$ & 64 & $99.1: 0.9$ & 4 & 0.3 & 68 & 76 & 5 \\
16 & $\mathrm{~A} 4 \mathrm{~N} 3$ & 66 & 30 & 20 & $97: 3$ & 49 & $98.7: 1.3$ & 1 & traces & 88 & 76 & 4 \\
17 & $\mathrm{P}(\mathrm{OPh})_{3}$ & 68 & 70 & 15 & nd & 15 & $81.9: 18.1$ & 1 & traces & 25 & 63 & 1 \\
\hline
\end{tabular}

${ }^{\text {[a] }}$ Metallic precursor: $\mathrm{RuCl}_{2}\left(\mathrm{PPh}_{3}\right)_{3}+20$ equiv. of ligand, except $\mathrm{P}(\mathrm{OPh})_{3}, 40$ equiv.; otherwise, see Table 1 .

Table 4: Influence of the ligand-to-metal ratio in the hydroformylation of 10 -undecenitrile by the $\mathrm{RuCl}_{2}\left(\mathrm{PPh}_{3}\right)_{3} / \mathrm{Biphephos} \mathrm{system.}^{\mathrm{a}}$

\begin{tabular}{ccccccccccccc}
\hline Entry & {$[\mathrm{L}] /[\mathrm{Ru}]$} & Time & $\mathbf{1}$ & $\mathbf{1 - i n t - x}$ & $\mathbf{1 - i n t - x}$ & $\mathbf{2 + 3}$ & $\mathbf{2 / 3}$ & $\mathbf{4}$ & $\mathbf{5}$ & $\begin{array}{c}\text { Conv. } \\
\mathbf{1}\end{array}$ & HF & TOF $^{\mathrm{f}}$ \\
\hline & & {$[\mathrm{h}]$} & {$[\%]^{\mathrm{b}}$} & {$[\%]^{\mathrm{b}}$} & $\boldsymbol{x}=\mathbf{0} / \mathbf{1}^{+}$ & {$[\%]^{\mathrm{b}}$} & $(\mathrm{l} / \mathrm{b})^{\mathbf{c}}$ & {$[\%]^{\mathrm{b}}$} & {$[\%]^{\mathrm{b}}$} & {$[\%]^{\mathrm{d}}$} & {$[\%]^{\mathrm{e}}$} & {$\left[\mathrm{min}^{-1}\right]$} \\
\hline 18 & 0 & 88 & 92 & 7 & $99: 1$ & 0 & - & 0.4 & 0 & 1 & 0 & - \\
19 & 2.4 & 90 & 59 & 12 & $97: 3$ & 27 & $99.1: 0.9$ & 2 & 0 & 37 & 79 & 1.4 \\
20 & 6.0 & 53 & 49 & 17 & $99: 1$ & 32 & $98.8: 1.2$ & 2 & 0.3 & 47 & 71 & 2.9 \\
21 & 10.5 & 73 & 40 & 22 & $97: 3$ & 35 & $99.1: 0.9$ & 3 & 0 & 57 & 66 & 2.6 \\
22 & 20 & 48 & 10 & 22 & $97: 3$ & 64 & $99.1: 0.9$ & 4 & 0.3 & 88 & 76 & 6.1 \\
\hline
\end{tabular}

[a] See Table 1.

Table 5: Influence of temperature in the hydroformylation of 10-undecenitrile by the $\mathrm{RuCl}_{2}\left(\mathrm{PPh}_{3}\right)_{3} /$ Biphephos system. ${ }^{\mathrm{a}}$ 


\begin{tabular}{ccccccccccccc}
\hline Entry & Temp & Time & $\mathbf{1}$ & $\mathbf{1 - i n t - x}$ & $\mathbf{1 - i n t - x}$ & $\mathbf{2 + 3}$ & $\mathbf{2 / 3}$ & $\mathbf{4}$ & $\mathbf{5}$ & $\begin{array}{c}\text { Conv. } \\
\mathbf{1}\end{array}$ & HF $^{\text {TOF }}$ & TOF $^{\mathrm{f}}$ \\
\hline & {$\left[{ }^{\circ} \mathrm{C}\right]$} & {$[\mathrm{h}]$} & {$[\%]^{\mathrm{b}}$} & {$[\%]^{\mathrm{b}}$} & $\boldsymbol{x}=\mathbf{0 / \mathbf { 1 } ^ { + }}$ & {$[\%]^{\mathrm{b}}$} & $(l / b)^{\mathrm{c}}$ & {$[\%]^{\mathrm{b}}$} & {$[\%]^{\mathrm{b}}$} & {$[\%]^{\mathrm{d}}$} & {$[\%]^{\mathrm{e}}$} & {$\left[\mathrm{min}^{-1}\right]$} \\
\hline 23 & 120 & 48 & 10 & 22 & $97: 3$ & 64 & $99.1: 0.9$ & 4 & 0.3 & 68 & 76 & 5 \\
24 & 140 & 63 & 1 & 40 & $88: 12$ & 54 & $98.7: 1.3$ & 5 & 0.3 & 99 & 58 & $11^{\mathrm{g}}$ \\
\hline
\end{tabular}

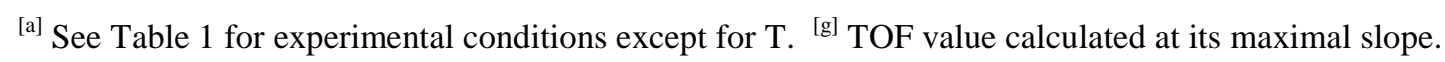

Table 6: Influence of total and relative pressures in the hydroformylation of 10-undecenitrile by the $\mathrm{RuCl}_{2}\left(\mathrm{PPh}_{3}\right)_{3} /$ Biphephos system. ${ }^{\mathrm{a}}$

\begin{tabular}{cccccccccccccc}
\hline Entry & $\mathrm{P}_{\mathrm{tot}}$ & $\mathrm{CO} / \mathrm{H}_{2}$ & Time & $\mathbf{1}$ & $\mathbf{1 - i n t - \boldsymbol { x }}$ & $\mathbf{1 - i n t - \boldsymbol { x }}$ & $\mathbf{2 + 3}$ & $\mathbf{2 / 3}$ & $\mathbf{4}$ & $\mathbf{5}$ & $\begin{array}{c}\text { Conv. } \\
\mathbf{1}\end{array}$ & $\begin{array}{c}\mathrm{HF} \\
\mathrm{TOF}^{\mathrm{e}}\end{array}$ \\
\hline & {$[\mathrm{b}$ ar $]$} & ratio & {$[\mathrm{h}]$} & {$[\%]^{\mathrm{b}}$} & {$[\%]^{\mathrm{b}}$} & $\boldsymbol{x}=\mathbf{0 / \mathbf { 1 } ^ { + }}$ & {$[\%]^{\mathrm{b}}$} & $(l / b)^{\mathrm{c}}$ & {$[\%]^{\mathrm{b}}$} & {$[\%]^{\mathrm{b}}$} & {$[\%]^{\mathrm{c}}$} & {$[\%]^{\mathrm{d}}$} & $\left(\mathrm{min}^{-1}\right)$ \\
\hline 25 & 10 & $1: 1$ & 63 & 24 & 23 & $97: 3$ & 50 & $99.3: 0.7$ & 3 & 1.1 & 74 & 72 & 3.9 \\
26 & 20 & $1: 1$ & 48 & 10 & 22 & $97: 3$ & 64 & $99.1: 0.9$ & 4 & 0.3 & 89 & 76 & 6.1 \\
27 & 20 & $1: 3$ & 55 & 58 & 18 & $99: 1$ & 14 & $98.9: 1.1$ & 5 & 5.7 & 38 & 40 & 2.3 \\
28 & 20 & $3: 1$ & 65 & 71 & 13 & $99: 1$ & 13 & $98.8: 1.2$ & 1 & 1.6 & 24 & 60 & 1.2 \\
29 & 40 & $1: 1$ & 46 & 43 & 15 & $98: 2$ & 39 & $98.9: 1.1$ & 2 & 0.6 & 54 & 77 & 3.9 \\
30 & 90 & $1: 1$ & 71 & 81 & 8 & $98: 2$ & 10 & $97.9: 2.1$ & 1 & 0.0 & 13 & 78 & 0.6 \\
\hline
\end{tabular}

${ }^{[a]}$ See Table 1 except for the $P$ value.

Table 7: Recycling of the $\mathrm{RuCl}_{2}\left(\mathrm{PPh}_{3}\right)_{3}$-Biphephos system over 3 runs in the hydroformylation of 10-undecenenitrile. ${ }^{\mathrm{a}}$

\begin{tabular}{cccccccccccc}
\hline Run & Biphephos & time & $\mathbf{1}$ & $\mathbf{1 - i n t - x}$ & $\mathbf{2 + 3}$ & $\mathbf{2 / 3}$ & $\mathbf{4}$ & $\mathbf{5}$ & $\begin{array}{c}\text { Conv. } \\
\mathbf{1}\end{array}$ & HF & TOF $^{\mathrm{f}}$ \\
\hline & {$[\mathrm{h}]$} & {$[\%]^{\mathrm{b}}$} & {$[\%]^{\mathrm{b}}$} & {$[\%]^{\mathrm{b}}$} & $(l / b)^{\mathrm{c}}$ & {$[\%]^{\mathrm{b}}$} & {$[\%]^{\mathrm{b}}$} & {$[\%]^{\mathrm{d}}$} & {$[\%]^{\mathrm{e}}$} & {$\left[\mathrm{min}^{-1}\right]$} \\
\hline 1 & - & 190 & 14 & 31 & 45 & $98.8: 1.2$ & 5 & 5 & 84 & 57 & 1.6 \\
2 & +20 equiv $^{\mathrm{g}}$ & 150 & 6 & 28 & 62 & $99.3: 0.7$ & 3 & 1 & 94 & 71 & 2.2 \\
3 & - & 124 & 3 & 27 & 64 & $98.9: 1.1$ & 5 & 1 & 99 & 72 & 2.7 \\
\hline
\end{tabular}

${ }^{[a]}$ See Table $1 .{ }^{[\mathrm{g}]} 20$ equiv of Biphephos (vs. Ru) were added to the solid residue before starting the $2^{\text {nd }}$ run. 


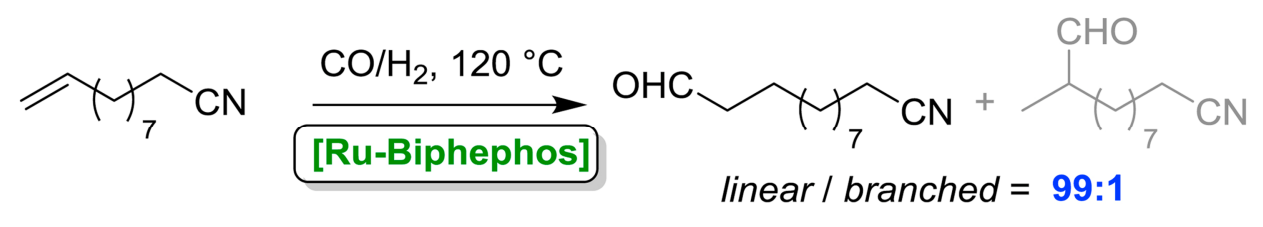

up to $75 \%$ chemoselectivity for aldehydes

TON up to $15,000 \mathrm{~mol}($ aldehyde $) \cdot \mathrm{mol}(\mathrm{Ru})^{-1}$ and TOF up to $310 \mathrm{~mol} \cdot \mathrm{mol}(\mathrm{Ru})^{-1} \cdot \mathrm{h}^{-1}$ $\mathrm{fx} 1$. 


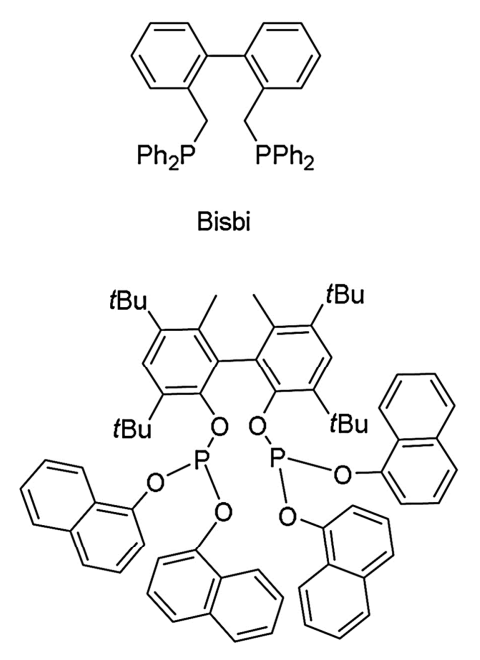

A4N3
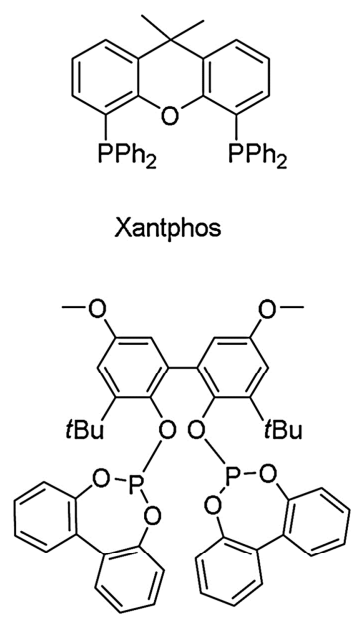

Biphephos

gr1 . 

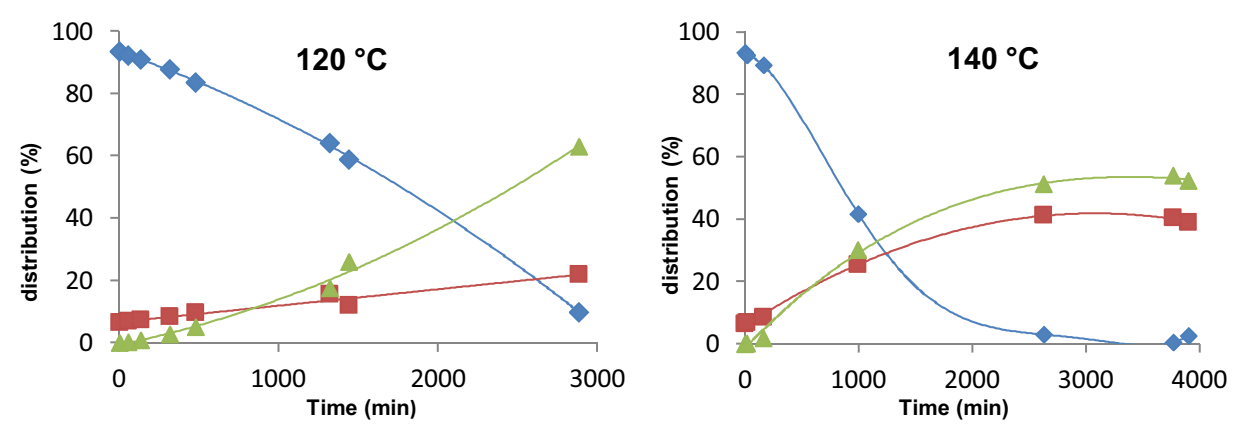

gr2 . 